\title{
Upwelling and Degree of Nutrient Consumption in Nanwan Bay, Southern Taiwan
}

\author{
Chen-Tung Arthur Chen \\ Institute of Marine Geology and Chemistry, National Sun Yat-sen University, Kaohsiung, Taiwan 804, R.O.C., \\ ctchen@mail.nsysu.edu.tw \\ Bing-Jye Wang \\ Institute of Marine Geology and Chemistry, National Sun Yat-sen University, Kaohsiung, Taiwan 804, R.O.C. \\ Li-Yu Hsing \\ Institute of Marine Geology and Chemistry, National Sun Yat-sen University, Kaohsiung, Taiwan 804, R.O.C.
}

Follow this and additional works at: https://jmstt.ntou.edu.tw/journal

Part of the Terrestrial and Aquatic Ecology Commons

\section{Recommended Citation}

Chen, Chen-Tung Arthur; Wang, Bing-Jye; and Hsing, Li-Yu (2004) "Upwelling and Degree of Nutrient Consumption in Nanwan Bay, Southern Taiwan," Journal of Marine Science and Technology. Vol. 12: Iss. 5, Article 11.

DOI: $10.51400 / 2709-6998.2266$

Available at: https://jmstt.ntou.edu.tw/journal/vol12/iss5/11

This Research Article is brought to you for free and open access by Journal of Marine Science and Technology. It has been accepted for inclusion in Journal of Marine Science and Technology by an authorized editor of Journal of Marine Science and Technology. 


\section{Upwelling and Degree of Nutrient Consumption in Nanwan Bay, Southern Taiwan}

Acknowledgements

We acknowledge the financial support of the Taiwan Power Company and National Science Council (NSC93-2611-M-110-009; 93-2621-Z-110-004). 


\title{
UPWELLING AND DEGREE OF NUTRIENT CONSUMPTION IN NANWAN BAY, SOUTHERN TAIWAN
}

\author{
Chen-Tung Arthur Chen, Bing-Jye Wang, and Li-Yu Hsing
}

Key words: Nanwan Bay, upwelling, dissolved organic nitrogen, degree of nutrient consumption.

\section{ABSTRACT}

The newly proposed Degree of Nutrient Consumption (DNC) of upwelled waters was used to evaluate the upwelling process in Nanwan Bay off the southern tip of Taiwan. DNC values were found to be low in subsurface waters or in newly upwelled waters. In general, a low DNC value was detected alongside other traditionally used upwelling indicators such as lower temperature, $\mathrm{pH}$ and \% oxygen saturation but higher salinity, nutrients and chlorophyll $a$. On the other hand, the DNC value could be several times higher in aged upwelled water found in the surface layer.

\section{INTRODUCTION}

Nanwan Bay, located at the southern tip of Taiwan (Fig. 1) adjacent to the Kenting National Park, is in a pristine marine environment with minimum industrial, domestic or agricultural pollution. The Third Nuclear Power Plant northwest of the bay, established before the national park, on the other hand, has been a concern as it draws cooling water from the bay and discharges it back into the bay. Because of the nature of the semienclosed bay, whether thermal pollution has harmed the coral community has been an issue. This is because if the warm effluent from the power plant re-circulates within the bay, temperature of the bay water may rise to an intolerable degree for corals.

However, the temperature data in and out of Nanwan Bay does not support a temperature buildup within the bay (Chen et al., 2001). In fact, when compared with sea surface temperature outside of the bay measured during the World Ocean Circulation Experiment (Fig. 2), Sts. 14, 16, 18, 20, 22 and 23 actually have a lower temperaute. This is consistent with the report of a cold eddy inside Nanwan Bay (Chen et al.,

Paper Submitted 11/03/04, Accepted 11/30/04. Author for Correspondence: Chen-Tung Arthur Chen. E-mail: ctchen@mail.nsysu.edu.tw.

*Institute of Marine Geology and Chemistry, National Sun Yat-sen University, Kaohsiung, Taiwan 804, R.O.C.
1994). In a series of papers Lee et al. (1997, 1999a, b) reported tidally induced upwelling, which brings cold water to the surface and may be used to explain the lower temperature in the bay compared with the higher temperature outside. Of note is that St. 24 is near the outlet of the thermal effluent and it has an higher temperature.

Such an upwelling not only helps keeping Nanwan Bay relatively cool despite the power plant, upwelling also has significant biogeochemical implications. This is because upwelled water supplies nutrients to the euphotic zone in the surface oceans and stimulates biological production. Most of the world's major fisheries, like those off Oregon, California, Peru, Namibia, Somalia, Vietnam and East China Sea, are known for their upwelling (Wong et al., 1991; Chen, 1996; Gong et al., 2000; Liu et al., 2000a, b, 2002). In fact, upwelling of nutrient-rich subsurface Kuroshio

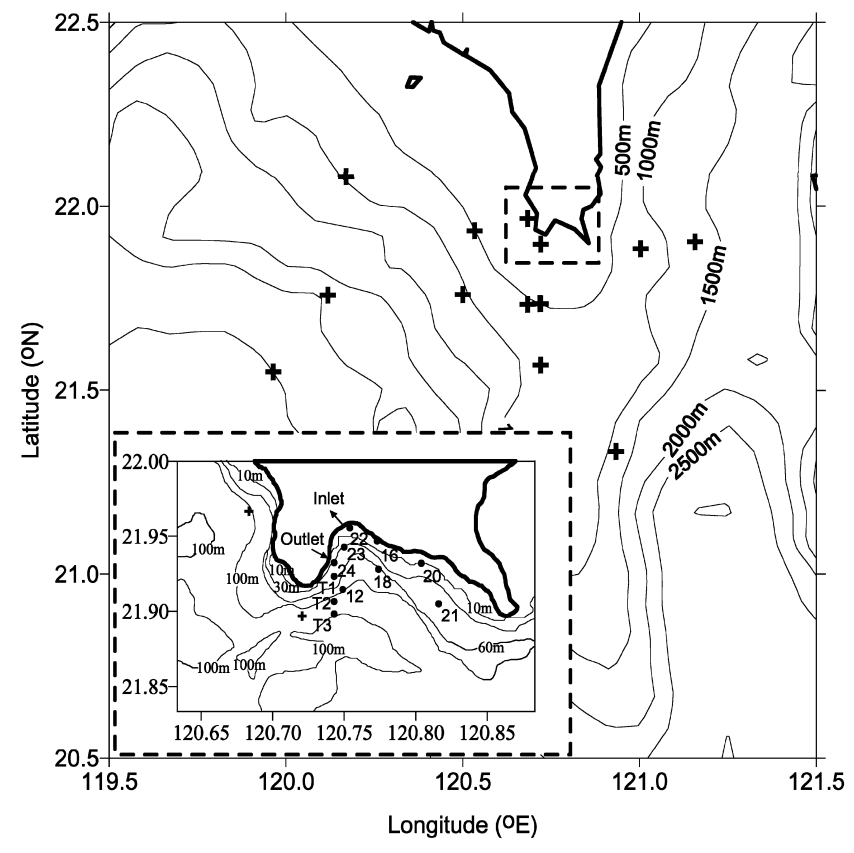

Fig. 1. Sampling stations in Nanwan Bay $(\bullet)$ and WOCE $(+)$ stations nearby. 
waters has been reported (Chen and Wang, 1999) to contribute over $70 \%$ of $\mathrm{P}$ which is needed to support total new production on the East China Sea continental shelf.

The importance of upwelling notwithstanding, it is not yet possible to measure upwelling directly. Traditionally, lower temperature, dissolved oxygen content and $\mathrm{pH}$, but higher salinity, nutrients and chlorophyll a have been used to identify upwelled water. However, solar heating, evaporation, precipitation, as well as river input and groundwater seepage tend to blur the temperature, salinity, and nutrient signals. Further, biological consumption may reduce nutrients while chlorophyll a is increasing. As a result, the upwelling center may actually have a negative correlation between nutrient content and chlorophyll $a$.

\section{DEGREE OF NUTRIENT CONSUMPTION}

Further clouding the relationships among nutrients, chlorophyll a and upwelling is that when the later process is intensive, the nutrient-rich subsurface waters may be diverged from the upwelling center before phytoplankton has a change to fully grow. Consequently, the chlorophyll $a$ concentration may actually be higher at the perimeter of the upwelling center. On the other hand, if the upwelling process is slow, phytoplankton can grow fully near the upwelling center, hence making

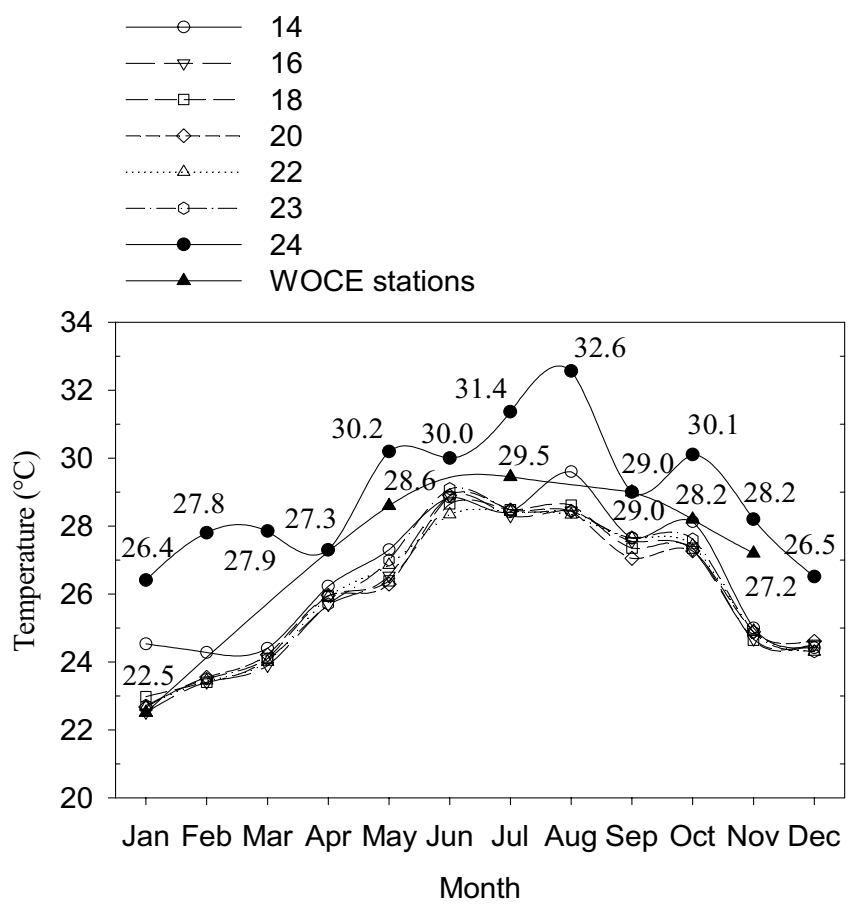

Fig. 2. Comparison of average sea surface temperature at seven stations within nanwan bay (1986-2003) and at WOCE stations nearby. the chlorophyll $a$ concentration high near the center. In the meantime, nutrient concentrations may be low near the center because of consumption (Chen et al., 2004).

In order to express the aging status of a given upwelled water mass, Takahashi et al. (1986) took into account the relative percentages of chlorophyll $a$ and nitrite plus nitrate. Chen et al. (2004) renamed the aging index of upwelling as Degree of Nutrient Consumption (DNC):

$$
D N C_{c}=\frac{0.7 \times \text { chlorophyll } \mathrm{a}}{N O_{3}^{-}+N O_{2}^{-}+0.7 \times \text { chlorophyll } \mathrm{a}}
$$

where subscript c refers to DNC based on chlorophyll $a$. A similar equation based on $P$ was proposed by Chen (2000):

$$
D N C_{P}=\frac{D O P+P P}{D I P+D O P+P P}
$$

where $D O P, D I P$ and $P P$ refer to dissolved organic $P$, dissolved inorganic $P$ and particulate $P$, respectively. Recently, Chen et al. (2004) proposed a similar equation based on $N$ :

$$
D N C_{N}=\frac{D O N+P O N}{D I N+D O N+P O N}
$$

where DON, PON and DIN are, respectively, dissolved organic $N$, particulate organic $N$ and dissolved inorganic $N$.

The rationale behind the above equations are that the subsurface waters contain high amounts of DIN and DIP but low amounts of chlorophyll $a$, DON, DOP, PP and DON. As a result, before upwelling the DNC is low. On the other hand, the DNC is high after most nutrients are converted to organic form in the euphotic zone. Chen et al. (2004) was the first to show that based on data in the literature, $\mathrm{DNC}_{\mathrm{N}}$ can be used not only to identify the upwelling phenomenon in Nanwan Bay, but also its strength. Because of the limitation in the available data, which were two decades old ( $\mathrm{Su}$ et al., 1985), Chen et al. (2004) were able to show only the average value for the $25 \mathrm{~m}$-thick upper water column, hence no vertical resolution. It is the purpose of this manuscript to show the upwelling phenomenon and $\mathrm{DNC}_{\mathrm{N}}$ in Nanwan Bay based on spatially and vertically distributed data. In addition, examples based on $\mathrm{DNC}_{\mathrm{C}}$ are also presented below.

\section{SAMPLING LOCATIONS AND ANALYTICAL METHODS}

The sampling locations are plotted in Fig. 1. Temperature and salinity were determined at 11 stations with a Sea-Bird 19 CTD (Conductivity-Temperature- 
Depth/Pressure) unit, and discrete samples were collected from eight stations using a Niskin bottle. Salinity in discrete samples was determined by measuring conductivity using an AUTOSAL salinometer 8400B calibrated with IAPSO standard seawater (batch no. P128) for a precision of 0.003 . Dissolved oxygen (DO) in discrete samples was measured by direct spectrophotometry (Pai et al., 1993). The precision of the measurement was about $0.32 \%$ at the $190 \mu \mathrm{mol} \mathrm{\textrm {kg } ^ { - 1 }}$ level. The apparent oxygen utilization (AOU) was calculated based on the oxygen solubility equation of Chen (1981). pH was measured at $25 \pm 0.05^{\circ} \mathrm{C}$ with a Radiometer PHM$85 \mathrm{pH}$ meter using a GK-2401C combination electrode. A Tris seawater buffer was used to calibrate the electrode. The precision was better than $\pm 0.003 \mathrm{pH}$ unit.

Nitrate $\left(\mathrm{NO}_{3}^{-}\right)$was measured by reducing nitrate to nitrite $\left(\mathrm{NO}_{2}^{-}\right)$and then determining the nitrite employing the pink azo dye method by using a flow injection analyzer with an on-line $\mathrm{Cd}$ coil. The precision of this method was about $\pm 0.08 \mu \mathrm{mol} \mathrm{L}^{-1}$ for $\mathrm{NO}_{3}{ }^{-}$and \pm 0.02 $\mu$ mol L ${ }^{-1}$ for $\mathrm{NO}_{2}{ }^{-}$. Phosphate $\left(\mathrm{PO}_{4}{ }^{3-}\right)$ was determined by the molybdenum blue method using a flow injection analyzer. The precision of the measurement was about $\pm 0.05 \mu \mathrm{mol} \mathrm{L}{ }^{-1}$. Silicate $\left(\mathrm{SiO}_{2}\right)$ was measured by the method of Fanning and Pilson (1973), also using a flow injection analyzer. The precision of the method was $\pm 0.1 \mu \mathrm{mol} \mathrm{L}^{-1}$. CSK standards in artificial seawater (Wako, Japan) were used for calibration (Pai et al., 1990; Chen et al., 2004).

DOP, DON and PON samples were collected by filtration through a precombusted $0.7 \mu \mathrm{m}$ Whatmann GF/F fiberglass filter. Total suspended matter and chlorophyll $a$ samples were collected by filtration through a $0.45 \mu \mathrm{m}$ diameter Millipore polycarbonate filter. A Turner Designs model 10-AU fluorometer was used to measure chlorophyll $a$ after extraction by $90 \%$

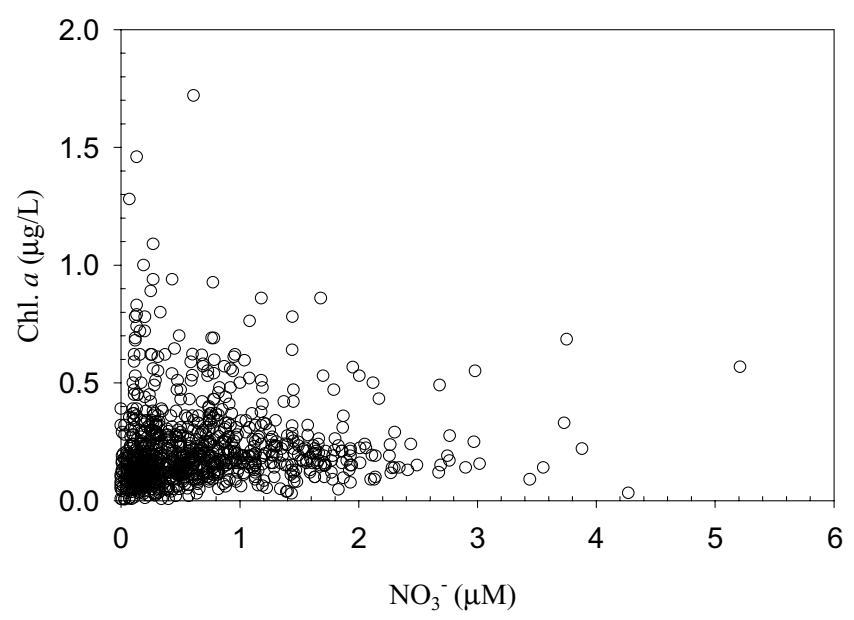

Fig. 3. Relationship between chlorophyll $a$ and nitrate (July, 1983Dec., 2003). acetone (Strickland and Parsons, 1972). A LECO CHN932 Elemental Analyzer was used to measure total particulate nitrogen $(\mathrm{PN})$ at $950^{\circ} \mathrm{C}$, with 11 pure and mixtures of NIST SRM-2704, LECO EDTA standard and sulfa-methazine used to calibrate the analyzer. A separate sample was burned at $450^{\circ} \mathrm{C}$ for 3 hours to remove organic matter and then remeasured with the Elemental Analyzer to obtain the value of particulate inorganic nitrogen. The difference between this value and PN determined PON. The method of Valderrama (1981) was followed to oxidize DOP and DON to $\mathrm{PO}_{4}{ }^{3-}$ and $\mathrm{NO}_{3}{ }^{-}$. Duplicate samples were run and the precision for DOP and DON was 24 and 8\%, respectively. Glycol and ATP (Sigma ultrapure) were used to prepare running standards.

\section{RESULTS}

First of all we looked at the relationship between chlorophyll $a$ concentration and nitrate based on data collected for this study and some of our unpublished data (Fig. 3). There seems to be a negative correlation which suggests that the study area is nutrient limited and the phytoplankton growth is out of phase with the nutrient supply. That is, phytoplankton starts to flourish when nutrient contents becomes high, and reaches the highest phytoplankton (chlorophyll a) stock while nutrients are near depletion. Subsequently, biological productivity is reduced to an extent when nutrient contents start to build up again, perhaps by upwelling. This indicates that upwelled waters do not necessarily contain higher $\mathrm{NO}_{3}{ }^{-}$or chlorophyll $a$. This is when DNC becomes useful because it indicates whether the upwelled water is new (lower DNC) or has been aged (higher DNC).

The spatial distributions of $\mathrm{T}, \mathrm{S}, \mathrm{pH}, \mathrm{DO}(\%)$, $\mathrm{NO}_{3}{ }^{-}, \mathrm{SiO}_{2}$, chlorophyll $a$ and $\mathrm{DNC}_{\mathrm{C}}$ in the surface layer in Oct. 2000 are given in Fig. 4-1. It is noted that near the center of the bay $\mathrm{T}, \mathrm{pH}$ and $\mathrm{DO}(\%)$ reveal a minimum whereas $\mathrm{S}_{1} \mathrm{NO}_{3}{ }^{-}$and $\mathrm{SiO}_{2}$ are high. Indeed, $\mathrm{DNC}_{\mathrm{C}}$ also shows a minimum near the center. This is a clear indication that upwelling near the center of the bay was strong so that a rather low $\mathrm{DNC}_{\mathrm{C}}$ value was maintained. Fig. 4-2 shows pretty much the same information at $10 \mathrm{~m}$ depth. Of note is that chlorophyll $a$ did not show either a maximum nor a minimum in the surface layer at the upwelling center (Fig. 4-1). At $10 \mathrm{~m}$ depth, chlorophyll $a$ was actually low near the upwelling center, perhaps because phytoplankton did not have enough time to fully grow. Chlorophyll $a$ values are higher at $10 \mathrm{~m}$ then at surface, a common phenomenon found in the oceans, especially in the tropics (Chen, 1994).

Fig. 4 was based on data in the fall when upwelling 
appears to be the strongest and the most frequent. The upwelling signal seems to be the weakest and the occurrence the least frequent in winter and early spring. Fig. 5-1 shows such a phenomenon detected in Jan. 1997. In
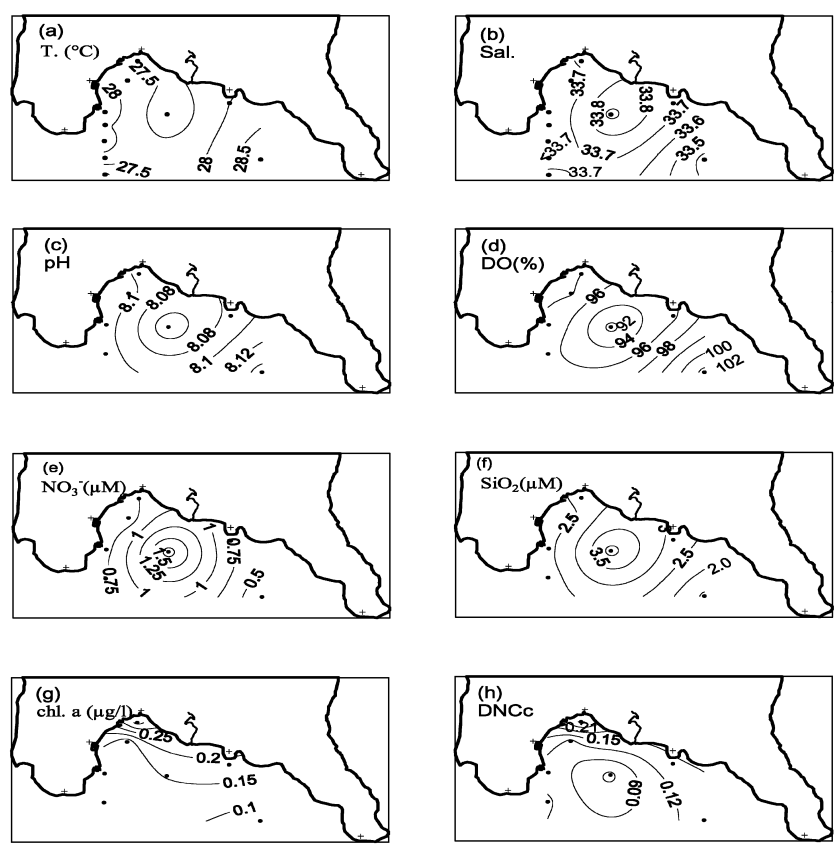

Fig. 4-1. (a) Temperature, (b) salinity, (c) pH, (d) DO (\%), (e) $\mathrm{NO}_{3}^{-}$, (f) $\mathrm{SiO}_{2},(\mathrm{~g})$ chl. $a$ and $(\mathrm{h}) \mathrm{DNC}_{\mathrm{C}}$ in the surface layer in Oct. 2000.
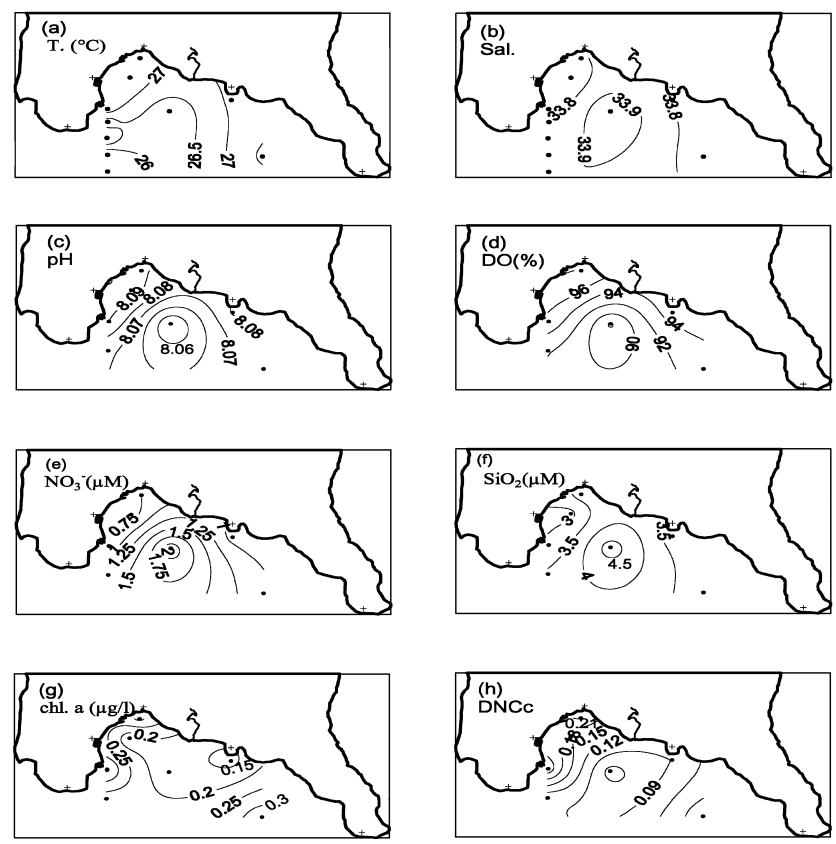

Fig. 4-2. (a) Temperature, (b) salinity, (c) pH, (d) DO (\%), (e) $\mathrm{NO}_{3}^{-}$, (f) $\mathrm{SiO}_{2}$, (g) chl. $a$ and (h) $\mathrm{DNC}_{\mathrm{C}}$ in the 10-m depth layer in Oct. 2000. this case, the upwelled water seems to have moved toward Sts. 16 and 22, rather than near the center of the bay (St. 18). Indeed, rapid temperature drops have been detected nearshore based on a recent continuous temperature record (Fig. 6). Upwelling becomes more apparent and increases in frequency in late May, shown as an example in Fig. 5-2. In this case, as most often
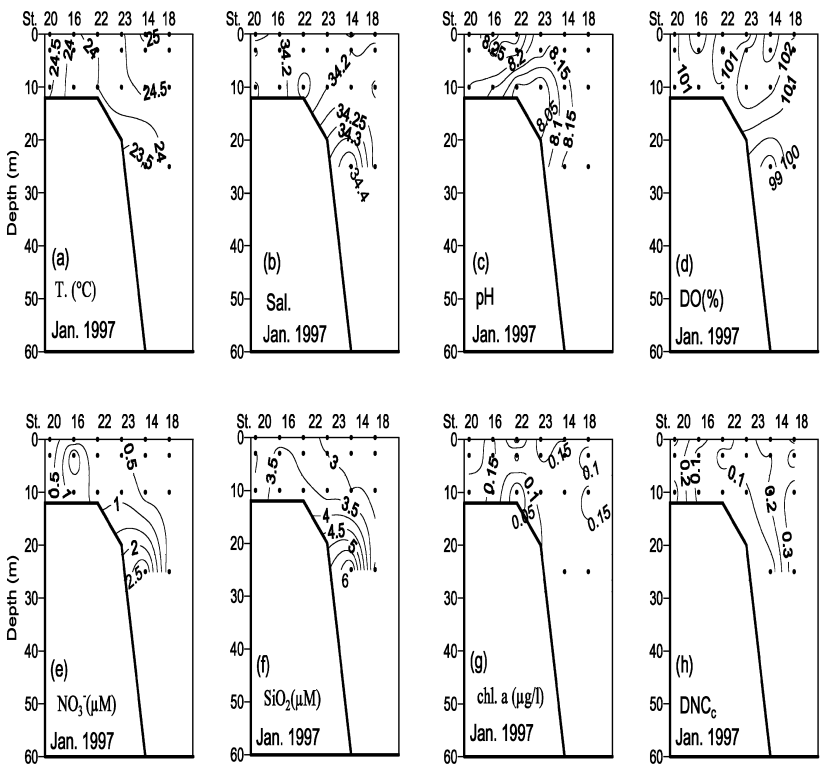

Fig. 5-1. Cross-sections of (a) temperature, (b) salinity, (c) pH, (d) DO (\%), (e) $\mathrm{NO}_{3}^{-}$, (f) $\mathrm{SiO}_{2}$, (g) chl. $a$ and (h) $\mathrm{DNC}_{\mathrm{C}}$ for Nawan Bay in Jan., 1997.
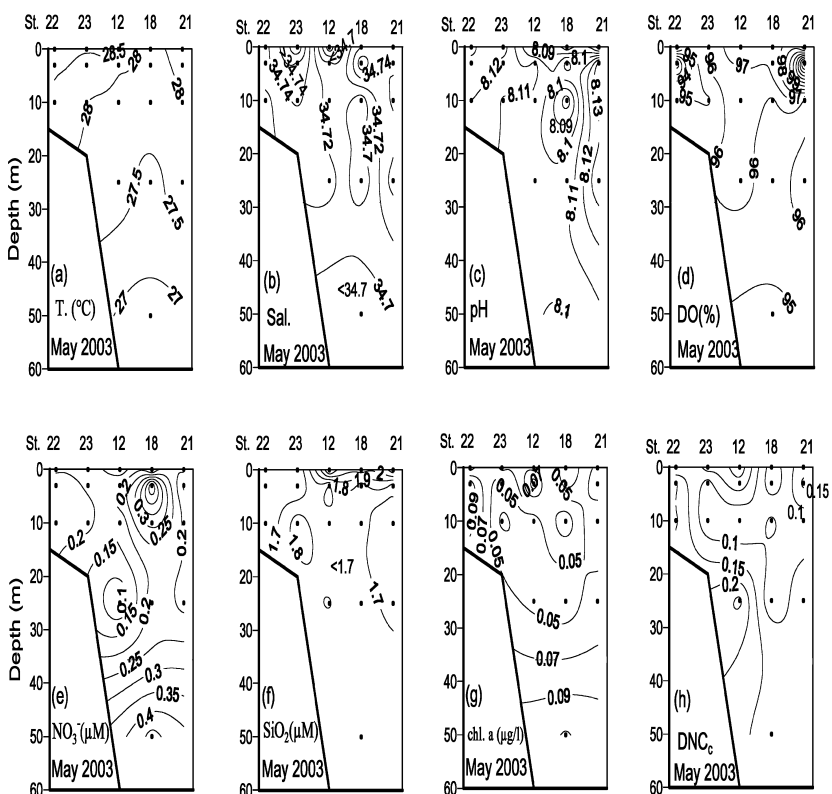

Fig. 5-2. Cross-sections of (a) temperature, (b) salinity, (c) pH, (d) DO (\%), (e) $\mathrm{NO}_{3}^{-}$, (f) $\mathrm{SiO}_{2}$, (g) chl. $a$ and (h) $\mathrm{DNC}_{\mathrm{C}}$ for Nawan Bay in May, 2003. 

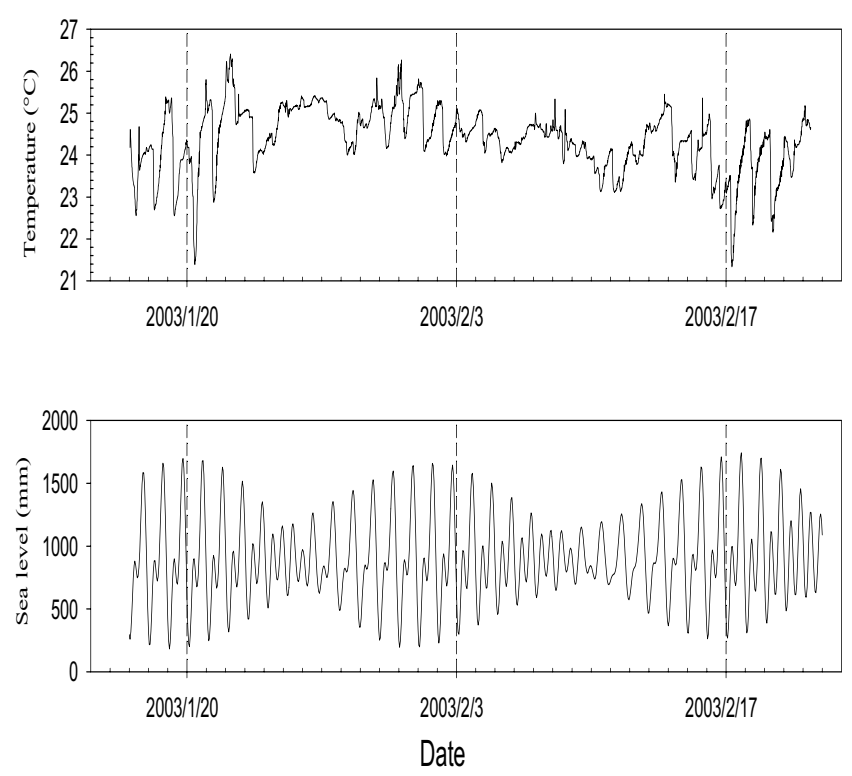

Fig. 6. Continuous temperature and tide record at St. 24 between 17 Jan and 21 Feb 2003.
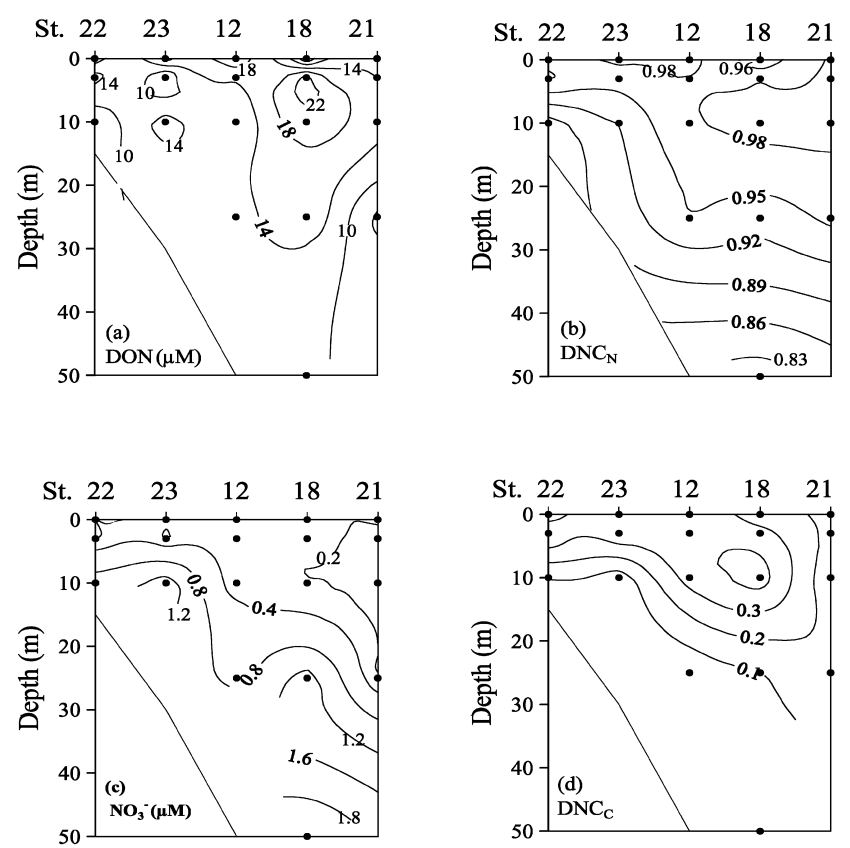

Fig. 7. Cross-sections of (a) DON, (b) $\mathrm{DNC}_{\mathrm{N}}$ (c) $\mathrm{NO}_{3}{ }^{-}$and (d) $\mathrm{DNC}_{\mathrm{C}}$ for Nanwan Bay.

found, the upwelling center is near St. 18 near the center of the bay.

\section{DISCUSSION}

Coastal processes are generally complicated with a lot of temporal and spatial variability. Topographical features, internal waves, winds and tides further complicate the upwelling issue even in a small bay such as Nanwan. It is shown that the DNC signal agrees qualitatively with the commonly used upwelling signals based on T, S, pH, \% oxygen saturation, chlorophyll $a$ and nutrients. The absolute values of $\mathrm{DNC}_{\mathrm{N}}$ and $\mathrm{DNC}_{\mathrm{C}}$ differ (Fig. 7). Nevertheless, both do show the same upwelling feature. More importantly, both provide a semi-quantitative way to indicate whether an upwelling water is new or aged.

\section{CONCLUSIONS}

In order to supplement the use of temperature and salinity as upwelling indicators, and to obtain a semiquantitative measure of the intensity of upwelling, the Degree of Nutrient Consumption was used to evaluate the upwelling process in Nanwan Bay. Upwelling seems to be the strongest and the most frequent in the fall, and the weakest and the least frequent in winter and early spring. It was found that when the upwelling was strong, chlorophyll $a$ was actually low near the upwelling center, perhaps because phytoplankton did not have enough time to fully grow.

\section{ACKNOWLEDGEMENTS}

We acknowledge the financial support of the Taiwan Power Company and National Science Council (NSC93-2611-M-110-009; 93-2621-Z-110-004).

\section{REFERENCES}

1. Chen, C.T., "Oxygen Solubility in Seawater," Solubility Data Series, Vol. 7, Oxygen and Ozone, Battino, R. (Ed.), Pergamon Press, New York, pp. 41-55 (1981).

2. Chen, C.T.A., "The Kuroshio Intermediate Water is the Major Source of Nutrients on the East China Sea Continental Shelf," Oceanol. Acta, Vol. 19, pp. 523-527 (1996).

3. Chen, C.T.A., "Vertical Distribution of $\mathrm{pH}$ and Fluorecence of the INDIGO 2 Expedition in the Western Tropical Indian Ocean," Terr. Atm. Oceanic Sci., Vol. 5, No. 1, pp. 77-90 (1994).

4. Chen, C.T.A. and Wang, S.L., "Carbon, Alkalinity and Nutrient Budget on the East China Sea Continental Shelf," J. Geophys. Res., Vol. 104, pp. 20675-20686 (1999).

5. Chen, C.T.A., Hsing, L.Y., Liu, C.L., and Wang, S.L., "Degree of Nutrient Consumption of Upwelled Water in the Taiwan Strait Based on Dissolved Phosphorus or Nitrogen," Mar. Chem., Vol. 87, pp. 73-86 (2004).

6. Chen, C.T.A., Liu, L.L., Ou, C.C., Chung, Y.C., 
Wu, C.C., and Cheng, L.L., "New-Shore Ecological Studies at the Third Nuclear Power Plant," Proceedings, Nuclear Regulatory Commission Symposium on Research Progress, November, 1994, Chungli, Taiwan, pp. V-19-V-25 (1994).

7. Chen, C.T.A., Wang, B.J., Wang, J.J., Tu, Y.Y., and Chang, W.C., "Changes in Seawater Temperature Over the Past Twenty-two Years and the Radioisotopes in a Coral in Nanwan Bay Near the Third Nuclear Power Plant," Acta Oceanogr. Taiwanica, Vol. 39, pp. 39-52 (2001). (in Chinese with English Abstract)

8. Chen, S.T., "The Study on Aging Index of Upwelling by the Contents of Several Species of Phosphorus," Acta Oceanol. Sinica, Vol. 22, pp. 51-59 (2000). (in Chinese with English Abstract)

9. Fanning, K.A. and Pilson, M.E.Q., "On the Spectrophotometric Determination of Dissolved Silica in Natural Waters," Anal. Chem., Vol. 45, pp. 136-141 (1973).

10. Gong, G.C., Shiah, F.K., Liu, K.K., Wen, Y.H., and Liang, M.H., "Spatial and Temporal Variation of Chlorophyll $a$, Primary Productivity and Chemical Hydrography in the Southern East China Sea," Cont. Shelf Res., Vol. 20, pp. 411-436 (2000).

11. Lee, H.-J., Chao, S.-Y., Fan, K.-L., and Liang, N.-K., "Flood-ebb Disparity of Tidally Induced Recirculation Eddies in a Semi-enclosed Basin: Nan Wan Bay," Cont. Shelf Res., Vol. 19, pp. 871-890 (1999a).

12. Lee, H.-J., Chao, S.Y., Fan, K.L., and Kuo, T.Y., "Tideinduced Eddies and Upwelling in a Semi-Enclosed Basin: Nan Wan," Estuar. Coast. Shelf Sci., Vol. 49, pp. 775-787 (1999b).

13. Lee, H.-J., Chao, S.-Y., Fan, K.-L., Wang, Y.-H., and Liang, N.-K., "Tidally Induced Upwelling in a Semi-enclosed Basin: Nan Wan Bay," J. Oceanogr., Vol. 53, pp. 467-480 (1997).

14. Liu, K.K., Iseki, K., and Chao, S.-Y., "Continental Margin Carbon Fluxes," The Changing Ocean Carbon Cycle: A Midterm Synthesis of the Joint Global Ocean Flux Study, Hanson, R.B. Ducklow, H.W., and Field, J.G. (Eds.), International Geosphere-Biosphere Programme Book Series, Cambridge University Press, Cambridge, pp. 187-239 (2000a).

15. Liu, K.K., Atkinsion, L., Chen, C.T.A., Gao, S., Hall, J.,
MacDonald, R.W., Talaue McManus, L., and Quinones R., "Exploring Continental Margin Carbon Fluxes on a Global Scale," EOS, Vol. 81, pp. 641-642, 644 (2000b).

16. Liu, K.K., Chao, S.Y., Shaw, P.T., Gong, G.C., Chen, C.C., and Tang, T.Y., "Monsoon-Forced Chlorophyll Distribution and Primary Production in the South China Sea: Observations and a Numerical Study," DeepSea Res. I, Vol. 49, pp. 1387-1412 (2002).

17. Pai, S.-C., Gong, G.-C., and Liu, K.-K., "Determination of Dissolved Oxygen in Seawater by Direct Spectrophotometry of Total Iodine," Mar. Chem., Vol. 41, pp. 343351 (1993).

18. Pai, S.-C., Yang, C.-C., and Riley, J.P., "Effects of Acidity and Molybdate Concentration on the Kinetics of the Formation of the Phosphoantimonyl Molybdenum Blue Complex," Anal. Chim. Acta, Vol. 229, pp. 115120 (1990).

19. Strickland, J.D.H. and Parsons, T.R., A Practical Handbook of Seawater Analysis, Fisheries Research Board of Canada, Ottawa, Canada (1972).

20. Su, C.C., Hung, T.C., Chiang, Y.M., Tan, T.H., Chang, K.H., Yang, J.C., Cheng, Y.M., Fan, K.L., and Chang, H. T., "An Ecological Survey on the Waters Adjacent to the Nuclear Power Plant in Southern Taiwan," VI. The Progress Report of the Sixth Year Study (1984-1985). National Scientific Committee on the Problems of Environment, Academia Sinica, Taipei, Special Pub., No. 28, p. 155 (1985).

21. Takahashi, M., Ishizaka, J., Ishimaru, T., Atkinson, L.P., Lee, T.N., Yamaguchi, Y., Fujita Y., and Ichimura, S., "Temporal Change in Nutrient Concentrations and Phytoplankton Biomass in Short Time Scale Local Upwelling Around the Izu Peninsula, Japan,” J. Plankton Res., Vol. 8, pp. 1039-1049 (1986).

22. Valderrama, J.C., "The Simultaneous Analysis of Total Nitrogen and Total Phosphorus in Natural Waters," Mar. Chem., Vol. 10, pp. 109-122 (1981).

23. Wong, G.T.F., Pai, S.C., Liu, K.K., Liu, C.T., and Chen, C.T.A., "Variability of the Chemical Hydrography at the Frontal Region Between the East China Sea and the Kuroshio North-east of Taiwan," Estuar. Coast. Shelf Sci., Vol. 33, pp. 105-120 (1991). 